\title{
ELITES TÉCNICAS, ESTADO E DESENVOLVIMENTO REGIONAL EM MINAS GERAIS NA ERA VARGAS ${ }^{1}$
}

\author{
Daniel Henrique Diniz Barbosa* \\ Lidiany Silva Barbosa*
}

\begin{abstract}
Este texto aborda o processo de desenvolvimento regional encetado em Minas Gerais, com particular ênfase na participação do corpo técnico regional ao longo das décadas de 1930 e 1940. Trata-se de um período de relevantes transformações no âmbito do poder público, sobretudo no tocante ao papel desempenhado pela ideologia e prática do planejamento e intervencionismo do Estado na esfera econômica, o que permitiu, no caso mineiro, a ascensão da categoria profissional do engenheiro às arenas decisórias do Estado, com repercussão na elaboracão e tentativa de implantacão de projetos voltados para o desenvolvimento econômico regional, notadamente nas áreas de agricultura e siderurgia. Este texto priorizará, para tanto, dois grupos específicos dentre essa elite técnica mineira: os ex-alunos da Escola de Minas de Ouro Preto e os alunos e professores da Escola Superior de Agricultura e Veterinária, de Viçosa. PALAVRAS-CHAVE: elites técnicas, desenvolvimento, agricultura, siderurgia, ESAV, EMOP.
\end{abstract}

Uma das muitas transformações que a década de 1930 levou a termo no Brasil foi a elevação da crença no conhecimento técnico como um dos pressupostos fundamentais para a boa condução da esfera pública (Gomes, 1994). Decorrente de crise mundial dos valores e instituições liberais (Hobsbawm, 1995), essa crença no conhecimento técnico projetava um período em que as grandes decisões do Estado não apenas poderiam como deveriam prescindir da política (compreendida em sua definição liberal). Antes, deveriam alicerçar-se no profissional específico que portas-

\footnotetext{
* Doutorando do Programa de Pós-Graduação em História Econômica da Universidade de São Paulo. Professor do Instituto Federal de Minas Gerais.

Rua: Pandiá Calógeras, 898 - Bauxita. Cep: 35400-000. Ouro Preto - Minas Gerais. danieldiniz@usp.br

* * Doutoranda do Programa de Pós-Graduação em História Social da Universidade Federal do Rio de Janeiro. Bolsista do CNPq e pesquisadora associada ao Núcleo de Pesquisa em História Econômica e Demográfica do Cedeplar-Face/UFMG. lidiany@cedeplar.ufmg.br

${ }^{1}$ Este trabalho é fruto de resultados convergentes das seguintes dissertações: Barbosa, Lidiany Silva. Roupa nova para a velha senhora agrária. Os engenheiros-agrônomos e a modernização do campo em Minas Gerais. UFV. Dissertação de Mestrado, 2004. Barbosa, Daniel Henrique Diniz. Os técnicos em ação: os engenheiros de Minas Gerais e as alternativas de desenvolvimento regional (1935-1945), UFMG. Dissertação de Mestrado, 2005.
}

se o conhecimento técnico que, por ser cientificamente desenvolvido e racionalmente orientado, estava mais apto a prover o Estado de soluções viáveis para seus problemas de ordem prática.

Essa matriz de pensamento, evidentemente, não surge na década de 1930, conquanto nela seja definitivamente consolidada. Antes, decorre de longo processo que, cientificamente, corresponde à ideia de predomínio da razão como forma de compreensão total do mundo, dos homens e, por decorrência, de suas experiências. Já no plano político, relaciona-se a amplo processo de sistematização da esfera pública, com vistas à modernização acelerada. Em ambos os casos, sublinha-se a razão científica como fonte sine qua non do progresso social e material dos homens, seja por meio da relação entre ciência e progresso, presente na matriz positivista (Kropf, 1994), ou mesmo na construção de um desenvolvimento capitalista autoritário e racional, caso da via prussiana, na Alemanha (Moore Jr., 1983), ou da grande, conquanto não única influência dos científicos, no México (Katz, 2002) - processos referentes à segunda metade do século XIX. 
Deve-se sublinhar, ainda, que, embora essa lógica racionalizante tenda a ser associada, no campo do desenvolvimento capitalista, às experiências notadamente autoritárias (caso da Alemanha e do México em fins do século XIX e da Turquia no início do século XX), ou às formulações teóricas que pressupunham concentração de poder (como a proposta positivista de ditadura republicana), ela não esteve ausente em situações de desenvolvimento capitalista baseado na democracia liberal burguesa. Ao se proceder, por exemplo, à observação acerca do papel assumido pela formação dos engenheiros nos Estados Unidos, em especial desde o último quartel do século XIX, perceber-se-á a relevância da razão científica frente aos desafios impostos ao crescimento capitalista. Graduar um engenheiro, na realidade norte-americana do Oitocentos, correspondia a fornecer a um indivíduo habilidades específicas que lhe possibilitassem atuar diretamente na esfera produtiva, como portador da prática racional e incontestável que tenderia a maximizar a lucratividade do empreendimento mesmo que fora da órbita da intervenção estatal (Noble, 1987).

Sublinha-se, aqui, a existência de uma aposta na razão científica como motor do incremento material, tanto em economias centrais como periféricas, cuja origem remonta ao século XIX, e que caracterizou, sobretudo, a interpretação ocidental acerca do melhor caminho para o desenvolvimento material das sociedades capitalistas. Resta evidente que tal matriz influencia de maneira definitiva tanto os setores diretamente interessados no desenvolvimento capitalista (notadamente a burguesia) como o próprio Estado, seja ele formatado como uma democracia burguesa ou como uma forma discricionária. E, também, que essa chave de pensamento está presente no período, mesmo que em graus variáveis, na maior parte dos Estados ocidentais - se bem que paralelamente ao predomínio político do liberalismo, até sua crise no entreguerras (Hobsbawm, 1995).

Especificamente no Brasil, cuja tradição bacharelesca de sua burocracia remonta à própria formação do corpo burocrático português (Carva- lho, 1981), a matriz científica pode ser observada ao longo de todo o período imperial, com especial ênfase no Segundo Império, ${ }^{2}$ e sobressai quando da emergência republicana. Assim, a influência do pensamento positivista tanto na Escola Politécnica do Rio de Janeiro como na elite política e econômica do Rio Grande do Sul, ${ }^{3}$ a lenta, mas efetiva, consolidação de espaços técnicos voltados à proposição de políticas ligadas ao desenvolvimento industrial, ${ }^{4}$ a "hausmannização" da reforma de Pereira Passos no Rio de Janeiro, dentre tantos outros destaques pontuais, sublinham que, no Brasil, a despeito de governo que adotava o preceito liberal clássico na República Velha, repercutiu os ecos de uma contundente agenda científica que, ao racionalizar o Estado e o setor produtivo, propunha-se a açular o próprio desenvolvimento capitalista.

É nesse sentido, portanto, que a década de 1930 pode ser compreendida como período privilegiado para a percepção da consolidação da influência da razão científica na agenda pública. Por um lado, pela elevação de lógica nova de orientação na arena pública, cujo expoente, Getúlio Vargas, estava ligado à região em que o pensamento positivista era determinante (Fonseca, 1993). ${ }^{5}$ Por

${ }^{2}$ Ver, por exemplo, o trabalho de Freitas (2002), sobre a Comissão Geológica do Império e a participação de Charles F. Hartt; os trabalhos de Lopes $(1996,1997)$ sobre o Museu de História Natural; Figueirôa (1997) sobre as ciências geológicas no Brasil; Koury (1998) sobre a obra de Silva Maia; Sá \& Domingues (1996) sobre o ensino das ciências naturais do Brasil; Carvalho (2002) sobre a instituição da Escola de Minas de Ouro Preto.

${ }^{3}$ Sobre a influência do positivismo na Politécnica do Rio de Janeiro, ver especialmente Carvalho (2002) e, no Rio Grande do Sul, ver Fonseca (1988).

${ }^{4}$ Casos de Ministérios como o de "Agricultura, Indústria e Comércio" ou de "Viação e Obras Públicas" ou órgãos a eles ligados, como o Serviço Geológico e Mineralógico do Brasil, todos fundados em 1909 (Dias 1994).

5 Parte-se, aqui, da proposição de Fonseca (1993) que, diferentemente de outros autores (como Lins, 1967 e Bodea, 1992), não acredita que a agenda varguista pós1930 seja necessariamente positivista. Antes, de acordo com Fonseca, a filiação de Vargas ao Positivismo é mediada por interpretação muito singular dessa matriz, em que o desenvolvimento capitalista (o progresso, portanto) somente poderia ser alcançado dentro da ordem constituída - mas é, por suposto, interpretação que descarta outra parte considerável do pensamento positivista. Essa interpretação (característica daquilo que Fonseca considera por "geração de 1907", notadamente aqueles que, junto de Vargas, participam do Partido Republicano RioGrandense, mas menos afeitos à ortodoxia positivista), além de ser cotejada com a própria especificidade do "positivismo varguista", tem de ser, também, considerada à luz das contingências do período pós Revolução de Outubro, que não necessariamente cumpriu uma agen- 
outro, pela própria crise do modelo liberal clássico, que, sobretudo no Ocidente, aprofundou a percepção de que o liberalismo político e econômico não mais atendia à nova realidade decorrente da Grande Depressão e acelerou a formatação de agenda que propunha, por meio da racionalização da administração, a saída para a crise capitalista (Hobsbawm, 1995). Além disso, no caso do Brasil, a tradição burocrática, caracterizada pela cultura bacharelesca, foi contraponto importante quando se formulou outro conceito de administração no Estado Novo. Essa oposição, por sinal, em muito repercutiu na ordem burocrática que se instituía e subsidiou o novo, autoritário e intervencionista papel reservado ao poder público na realidade política e administrativa em formação. Uma nova ordem burocrática, composta por corpo técnico academicamente próximo do ideal científico e racional que se procurava impor.

Das profissões liberais ${ }^{6}$ consolidadas desde o período imperial brasileiro, seria a categoria profissional do engenheiro aquela que, de forma definitiva, iria se inserir no Estado, como portadora de conhecimento racional e, principalmente, aplicável.

Portanto, o engenheiro foi, a partir da década de 1930, o profissional de corte ideal para os desígnios estatais. De tal sorte que, de um modo geral, pode-se perceber, na organização do serviço público e na formulação dos órgãos deliberativos e consultivos definidores de políticas públicas de desenvolvimento econômico, a expressiva inserção dessa categoria a partir de então (Dias, 1994).

Importante frisar, por decorrência, que esse cenário pode ser desenhado para a questão nacio-

da Rio-Grandense, mas que, na verdade, formulou-se a partir de intrincada conexão de interesses, projetos e concepções ideológicas não necessariamente homogêneos. Ou, nos dizeres de Fonseca: "a ideologia do governante não é necessariamente a do governo. Mesmo se admitindo a filiação irrestrita de Vargas ao positivismo na República Velha, nada garantiria ter-se ela estendido ao conjunto da equipe governamental após 1930" (1993, p. 418). Logo, sugere-se que, mesmo que Vargas propusesse a supremacia da ciência ante a política ou da Administração e da Economia frente ao Direito e à Filosofia, isso não o torna ortodoxamente positivista, conquanto, de um lado, reflita a influência dessa matriz sobre seu pensamento e, de outro, reforce o argumento sobre seu pensamento e, de outro, reforce o argumento
aqui trabalhado da valorização do pensamento racional em detrimento do fazer político clássico (Idem, p. 418).

${ }^{6}$ Por profissões liberais toma-se definição utilizada por Coelho (1999). nal bem como para realidades regionais mais específicas. É o caso de Minas Gerais, que assiste, na década em questão, à emergência e à consolidação de corpo técnico predominantemente formado por engenheiros, na órbita de seu poder público regional (Diniz, 1981). Assim, a categoria profissional do engenheiro será, no caso mineiro de um modo muito específico, a portadora de um discurso "modernizante", que propunha dinamizar a economia regional, ${ }^{7}$ compreendida em situação de atraso relativo pela elite política e econômica mineira desde o princípio do século XX. ${ }^{8}$

Se o discurso da referida fração da elite mineira defendia a intervenção técnica nos desígnios econômicos regionais - visando a modernizá-los o fazia atentando para setores tradicionais da região mineira, a saber: agricultura e siderurgia. A escolha de ambos os setores, entretanto, não pode ser datada da década de 1930. Antes, já em 1903, quando da realização do I Congresso Agrícola, Industrial e Comercial de Minas Gerais, ${ }^{9}$ a elite mineira havia traçado um projeto de desenvolvimento econômico que superasse o atraso (ou percepção do), pautado por política de diversificação produtiva, modernização agrária e política mineral arrojada (Dulci, 1999). Esse projeto, contudo, ganhou efetividade apenas parcial e, a partir dos anos 1930, ascende à posição central no quadro da concepção e implementação de políticas de desenvolvimento regional.

7 Sobre o discurso do "novo" e do "moderno" e sua propriedade relacionada à categoria profissional do engenheiro em Minas Gerais, ver Barbosa (1993).

${ }^{8}$ Sobre a perspectiva do atraso econômico e as necessidades de suplantá-lo, ver Paula (2000). Sobre a discussão acerca do atraso relativo da economia mineira, sobretudo em relação à industrialização de São Paulo, ver Dulci (1999).

${ }^{9}$ Evento concretizado por Francisco Sales, então presidente do estado, conjuntamente com parcela da elite regional mineira. No encontro, temas relativos ao desenvolvimento de Minas foram marcantes, bem como a discussão acerca das melhores formas de intervenção na economia. Tal intenção do projeto pode ser percebida nas dilatadas comissões temáticas que foram criadas no evento: agricultura, café, pecuária, vinicultura e viticultura, indústria, tecido e fiação, curtume, mineração e águas minerais, bancária, comércio, viação férrea e estradas de rodagem (Faria, 1992). Uma observação no diário oficial Minas Gerais, publicado no período de realização do evento, demonstra a importância assumida pelas chamadas Comissões Fundamentais, tanto para a preparação do Congresso, como para determinar a relevância de João Pinheiro da Silva para o evento. Ex-presidente do estado, João Pinheiro tem, no I CAIC, seu retorno à vida pública, tendo inclusive o presidido. 
Nesses termos, será tanto uma política agrícola (diversificada e moderna) como uma política minero-siderúrgica que serão defendidas pelo corpo técnico que ascende às dianteiras decisórias regionais, quando do Governo ${ }^{10}$ de Benedito Valadares. ${ }^{11}$

Duas instituições de ensino serão, nesse sentido, fundamentais no que concerne à gestação de ambos os discursos, justamente por serem espaços de formação de boa parte do corpo técnico aqui em questão: a Escola de Minas de Ouro Preto (EMOP) e a Escola Superior de Agricultura e Veterinária, de Viçosa (ESAV). Além da formação técnica que ofertavam, conquanto em áreas distintas, ambas as instituições proporcionaram aos seus alunados, percepção quase missionária acerca de suas tarefas profissionais.

Em linhas gerais, as escolas estavam a formar profissionais cônscios de uma suposta responsabilidade inadiável: superar o atraso mineiro. Aos esavianos deveria ser de competência a necessária modernização agrária, priorizando a ação individual em relação ao homem do campo. Já aos emopianos deveria caber o projeto estatal de de-

${ }^{10}$ Adotou-se, neste artigo, a denominação governador para aqueles que governaram os estados pós-1930, não obstante a vigência do regime de interventorias seja registrada na maior parte da Era Vargas. A explicação para essa escolha reside no fato de que, em Minas Gerais, a existência do regime de interventorias ocorreu em alguns períodos da Era Vargas, mas não na totalidade. Entre 1930 e 1933, por exemplo, Olegário Maciel havia sido eleito e fora mantido no cargo por Vargas. Não era portanto, interventor. Mesmo Valadares, que assume como interventor em dezembro de 1933, elege-se governador em 1935, embora eleito pela Assembleia Legislativa e não em sufrágio universal, quando da vaga liberal aberta pela promulgação da Carta de 1934. Valadares mantém-se no poder em 1937, então novamente como interventor. Para se evitar, portanto, qualquer tipo de confusão, optou-se por considerar tanto Maciel como Valadares como governadores de Estado, diferentemente de todos aqueles que o governaram até 1930, que, por definição da Carta de 1891, eram considerados presidentes dos estados federados dos Estados Unidos do Brasil. Assim, a nomeação aqui utilizada segue a lógica constitucional dos específicos recortes.

${ }^{11}$ O Governo Benedito Valadares (1933-1945) representou a política de interventoria regional organizada por Vargas a partir de 1930, não obstante, conforme se aponta na nota anterior, tenha também sido eleito quando do pleito indireto de 1935. No caso mineiro, em específico, Valadares somente assume em 1933, devido a morte de Olegário Maciel que, embora não fosse interventor, era apoiador de Vargas, logo, não sendo substituído de imediato com o movimento revolucionário de 1930. O Governo Valadares será importante centro aglutinador do corpo técnico mineiro, será relevante no que concerne à propulsão de políticas públicas desenvolvimentistas, além de, inclusive, ser fundamental na centralização das elites regionais em torno do Estado. senvolvimento siderúrgico. Frente às permanências no universo rural de Minas Gerais, emergiam os gigantes ${ }^{12}$ da ESAV; aos que não creditavam excelência às potencialidades siderúrgicas mineiras, insurgiam os modernos bandeirantes ${ }^{13}$ da EMOP.

Gradativamente, conquistando espaços importantes na arena pública mineira, ambos os grupos se congraçavam, primordialmente, na Secretaria de Agricultura, Indústria, Comércio, Trabalho, Viação e Obras Públicas, ${ }^{14}$ comandada por nove anos (1933-1942) pelo emopiano Israel Pinheiro e, segundo Diniz (1981), órgão que seria o “embrião da tecnocracia mineira”. Por meio dessa importante secretaria, o corpo técnico pôde não apenas definir as bandeiras desenvolvimentistas; antes, pôde tentar efetivá-las. Para tanto, os engenheiros apoiaram-se em discurso apresentado como rigorosamente técnico que, por consequência, sugeria-se praticamente inquestionável.

Tomando por meio de divulgação do pensamento técnico algumas publicações voltadas tanto para seus pares como para o público em geral, o corpo técnico que gravitava em torno do poder público mineiro constituiu um discurso coeso, almejando a defesa de seus pressupostos desenvolvimentistas para Minas Gerais. ${ }^{15}$ Neste

${ }^{12} \mathrm{O}$ termo gigantes era utilizado como referência aos formados pela ESAV na década de 1930 (Barbosa, 2004).

${ }^{13} \mathrm{O}$ termo bandeirantes dos tempos modernos fora cunhado por ex-alunos de Ouro Preto para descreverem a atuação do grupo em relação ao desenvolvimento mineiro (Roque, 1999).

${ }^{14}$ A Secretaria de Agricultura, Indústria, Comércio, Trabalho, Viação e Obras Públicas funcionou entre 1933 e 1935. A partir de então, transformou-se em duas pastas: Secretaria de Agricultura, Indústria, Comércio e Trabalho e Secretaria de Viação e Obras Públicas. Apesar de separadas, atuavam politicamente muito próximas, ao menos ao longo da gestão de Valadares.

${ }^{15}$ Por desenvolvimentismo utilizamos a conceituação de Dulci: "Desenvolvimento, no terreno socioeconômico, é uma ideia referente à superação intencional de uma situação de atraso relativo. Envolve, portanto, uma clara dimensão política, que se traduz em ações governamentais - mediante graus variáveis de intervenção - e também em articulações de classes e grupos diversos (sobretudo as elites políticas, econômicas e intelectuais) em torno da meta de superação do atraso. Podemos chamar de desenvolvimentismo ao pensamento que focaliza esse processo numa perspectiva de projeto, realçando seu sentido estratégico e seu potencial mobilizador" (2005, p.114). Cumpre ressaltar que tal interpretação refere-se ao contexto regional e à possibilidade de vigorar, localmente, uma política desenvolvimentista específica, não dialogando necessariamente com o debate acerca do desenvolvimentismo brasileiro. Sobre o pensamento desenvolvimentista brasileiro, ver Bielschowsky (2000). 
texto, portanto, abordaremos as especificidades do discurso desenvolvimentista de esavianos e emopianos, intentando observar tanto a influência da matriz institucional de ambos os grupos como as características distintivas de seus projetos.

\section{OS EMOPIANOSE O DESENVOLVIMENTO MINEIRO: a defesa da siderurgia}

A Escola de Minas de Ouro Preto (EMOP), inaugurada em 1876, foi um dos mais importantes espaços de formação da elite brasileira entre o final do século XIX e início do século XX, sendo mesmo a segunda escola de engenharia civil brasileira (Carvalho, 2002). Fundada sob os auspícios de D. Pedro II e organizada pelo professor francês Claude Henri Gorceix, a EMOP teve, desde o início de suas atividades, uma preocupação primordial: desenvolver pesquisa cujo resultado fosse aplicável, gerando riqueza e desenvolvimento para Minas Gerais. ${ }^{16}$ Os trabalhos de pesquisa dos primeiros formandos da instituição já comprovam a relação imediata entre necessidades prementes da região de Ouro Preto e os objetos de estudo escolhidos (Roque, 1999). ${ }^{17}$

Da EMOP saíram engenheiros de minas, metalurgistas e civis ${ }^{18}$ em pequena quantidade,

${ }^{16}$ Essa é, por sinal, a tônica do discurso de inauguração proferido pelo seu primeiro diretor, Gorceix, em 1876 (citado em Barbosa, 2005).

${ }^{17}$ Carvalho (2002) aponta que a Escola havia sido criada mais por vontade política que por necessidade econômica efetiva. Entretanto, cabe notar que dada a realidade econômica mineira, dada também a questão do atraso relativo anteriormente abordada, o estabelecimento de instituição voltada para a pesquisa minero-siderúrgica em fins do século XIX pode ser, sim, observada como tentativa de se potencializar a indústria em Minas, mesmo que indústria incipiente, mesmo sendo posição individual de Pedro II, discordante da maioria dos políticos mineiros de então. Mas atente-se: embora o Imperador possa ser considerado fundamental, há de se questionar a leitura de que teria decidido pela Escola, devido a um interesse pessoal pelas ciências (hipótese cogitada por Lima, 1977). A Comissão Geológica do Império, fundada pouco antes que a EMOP, pelo próprio Pedro II, naufragou sem que ele tentasse socorrê-la, no mesmo ano de fundação da Escola (Freitas, 2002). Os estudos iniciais promovidos pela instituição ouro-pretana comprovam seu alto interesse pelos problemas siderúrgicos locais, propondo soluções viáveis para sua expansão. A esse respeito, ver Roque (1999).

${ }^{18}$ Originalmente, engenheiros de minas, os alunos da EMOP, já em 1882, passaram a contar com o título de durante suas primeiras décadas de funcionamento. ${ }^{19}$ Embora poucos, ocuparam importantes espaços no poder público federal, já desde 1909, com a fundação do Serviço Geológico e Mineralógico do Brasil que, dentre outros, compunha seus quadros essencialmente com exalunos de Ouro Preto (Carvalho, 2002). ${ }^{20}$ Já no poder público estadual, a participação de emopianos até 1930 foi residual, em que pese constante. Número importante de ex-alunos migrou, também, para o serviço privado, fundando siderúrgicas ou atuando em outras cujos proprietários não possuíam formação técnica, além de parcela que se dedicou ao serviço ferroviário. Seja no poder público ou na iniciativa privada, portanto, dificilmente estavam afastados dos negócios ligados à mineralogia e à siderurgia mineiras. ${ }^{21}$

Seja pela presença restrita na dianteira decisória do poder público regional até 1930, ou pela própria opção do referido poder pelas questões agrícolas no mesmo período, os engenheiros de Minas, oriundos da EMOP, em que pese tenham participado de boa parte dos projetos siderúrgicos regionais, não possuíam, até a década em questão, um discurso forte e coeso em torno do tema. Embora vez ou outra o assunto emergisse, e a contribuição de um proeminente ex-aluno fosse fundamental ${ }^{22}$, de uma maneira geral apenas quando, com o Governo Valadares, os engenheiros

engenheiros de minas, metalurgistas e civis, três especialidades reunidas em um título apenas. Conforme Carvalho (2002), por necessidade de inserção no mercado profissional, mais que por necessidade acadêmica.

${ }^{19}$ Sobre o pequeno número de alunos formados por turma, cabe uma consulta ao catálogo A Escola de Minas de Ouro Preto, em que é elaborada listagem que elenca todos os alunos que se graduaram pela EMOP em seus primeiros noventa anos. Em média, nos primeiros trinta anos de funcionamento do estabelecimento, graduavam-se apenas de três a cinco alunos por turma. Ver nota 26 .

${ }^{20}$ Ver, além de Carvalho, Dias (1994) e Kropf (1994).

${ }^{21}$ Ver o catálogo A Escola de Minas de Ouro Preto, já citado, em sua seção "Biografias". Cabe, também, consulta às páginas da Revista Mineira de Engenharia e da Revista da Escola de Minas. Principalmente no caso da primeira, serão constantes as reportagens sobre as "históricas” siderúrgicas de Minas Gerais e seus "pais fundadores".

${ }^{22}$ O caso "Itabira Iron” é exemplar nesse sentido, posto ter mobilizado ex-alunos da EMOP desde o seu início, na década de 1910 (Barbosa, 1993). 
emopianos assumem espaço decisório ${ }^{23}$ é que formulam discurso desenvolvimentista definitivo para o estado de Minas Gerais. E, evidentemente, o formulam tendo por eixo o desenvolvimento siderúrgico do estado, em detrimento de qualquer outro ramo econômico.

Foi por meio da Revista Mineira de Engenharia, fundada em 1938 sob os cuidados da Sociedade Mineira de Engenheiros, que o corpo técnico em geral (e os emopianos em particular) divulgou seu projeto de desenvolvimento baseado na perspectiva da grande siderurgia. Nesses termos, do conjunto que a Revista publicou, entre a sua fundação e o ano de 1955, 35\% dele contemplava a discussão da grande siderurgia mineira. Consecutivamente, 78\% do que se publicou sobre siderurgia nas páginas da Revista se concentrou entre 1938 e $1942,{ }^{24}$ sendo que $70 \%$ de tudo que foi publicado sobre o tema era assinado por emopianos. ${ }^{25}$

Aqueles que publicavam nas páginas da Revista, não raro, estavam também atuando nas secretarias de governo voltadas para o trabalho técnico. Se 70\% de tudo o que se publicou sobre siderurgia era assinado pelos emopianos, cumprenos lembrar que, na década de 1930, 45\% dos técnicos alojados em funções estatais, exercendo papéis estritamente técnicos, também eram emopianos. ${ }^{26} \mathrm{De}$ uma maneira geral, levavam para as páginas da Revista Mineira de Engenharia uma discussão que, de certo modo, frequentava o poder público regional: a implantação da grande siderurgia nacional.

${ }^{23}$ Sobre a ascensão dos emopianos aos espaços decisórios da administração pública mineira no Governo Valadares, ver Diniz (1981e 2002), Dulci (1999), Barbosa (1993) e Roque (1999).

${ }^{24}$ Período de consolidação de projeto de desenvolvimento siderúrgico nacional voltado para Minas Gerais, mas não efetivado, conforme discutiremos adiante.

${ }^{25}$ Essas informações têm por base dados retirados de levantamento procedido em Revista Mineira de Engenharia, $\mathrm{n}^{\circ} 1$ ao $\mathrm{n}^{\circ} 58$ publicados entre1938 e 1955.

${ }^{26}$ Sobre esse índice, ver levantamento procedido por Roque (1999). Deve-se atentar que o número de formados pela Escola era muito pequeno, ainda por volta da década de 1940. Selecionamos, em caráter de exemplificação, anos distintos, separados cada qual por uma década, partindo da primeira turma até a década de 1940. 1878: 3 graduados; 1888: 6 graduados; 1898: 7 graduados; 1908: 1 graduado; 1918: 11 graduados; 1928: 20 graduados; 1938: 15 graduados e; 1948: 15 graduados. Fonte: A Escola de Minas - 1876-1966. Ouro Preto: Oficinas Gráficas da Escola Federal de Minas de Ouro Preto, 1966.
Assunto recorrente desde, ao menos, a emergência da discussão em torno do caso Itabira Iron Ore $\mathrm{Co.}^{27}$, a questão da grande siderurgia brasileira mobilizou os técnicos mineiros em geral, e os emopianos em específico. Sendo os principais formuladores de projeto desenvolvimentista baseado na industrialização pesada, aos emopianos coube o papel de formuladores de uma proposta de intervenção estatal em prol da constituição de parque industrial siderúrgico nacional no território de Minas Gerais. Evidentemente, não respondiam aos anseios imediatos das elites mineiras. Antes, respondiam à própria especificidade de suas formações, já que haviam se graduado engenheiros de minas, além de firmarem-se contra posição relativamente hegemônica entre setores técnicos ligados ao Governo Central que, além de predominantemente compostos por graduados pela Escola Politécnica do Rio de Janeiro, formulavam projeto nacional de implantação da grande siderurgia, amparados pelo Governo Vargas, mas que tivesse como centro o Rio de Janeiro, não Minas Gerais. ${ }^{28}$

O problema que se apresentava, então, era não apenas definir para as elites mineiras a questão da grande siderurgia como algo viável para a superação do atraso econômico regional. Antes, era convencê-la e, por conseguinte, convencer o Governo Central que apenas Minas Gerais poderia ser sede de projeto de tal envergadura. Isso por dois motivos

27 A primeira legislação a respeito do subsolo brasileiro data de 1917. Obra do ex-aluno da EMOP João Pandiá Calógeras, respondia às pressões dos engenheiros brasileiros que percebiam, na regulamentação proveniente da Carta Constitucional de 1891 (acerca do subsolo nacional), uma afronta às riquezas pátrias. Isso porque, em linhas gerais, a referida constituição garantia ao proprietário do solo, no Brasil, pleno e total direito sobre o subsolo correspondente. Dada a excelente qualidade do minério de ferro brasileiro,e das facilidades de extraí-lo (além das facilidades em possuir suas jazidas), uma grande quantidade de empresas estrangeiras passou, a partir do início da década de 1910, a adquirir parcelas importantes do território brasileiro. Mais precisamente, colocaram-se a adquirir terras em que o subsolo fosse valioso em jazidas de minério de ferro. Apenas com a regulamentação de legislação a respeito do subsolo (a Carta das Minas, de Calógeras, em 1915) é que a situação seria regularizada. A empresa Itabira Iron Ore Co., entretanto, já havia adquirido importante território na cidade de Itabira, Minas Gerais, iniciando sua exploração. Além disso, cabia à empresa a exclusividade no transporte, via ferrovia, do minério de ferro extraído.

${ }^{28}$ Sobre esse projeto, ao qual nos remeteremos rapidamente adiante, ver Vargas (1994). 
capitais. Em primeiro lugar, porque apenas Minas possuía corpo técnico competentementeformado para o trabalho com a grande siderurgia e, por conseguinte, apenas o estado mineiro possuía as condições naturais ideais para a implantação do projeto, ao menos na leitura que o grupo empreendia.

De uma maneira geral, a proposta de grande siderurgia formulada pelo grupo emopiano e divulgada pela Revista Mineira de Engenharia defendia a adoção de política pública intervencionista e profundamente nacionalista no que tange aos rumos a serem definidos para a questão. ${ }^{29}$ Segundo a visão do corpo técnico de Minas, o Governo Central deveria, por meio do Banco do Brasil, financiar o investimento siderúrgico, prescindindo de qualquer apoio estrangeiro. ${ }^{30}$ Consecutivamente, deveria também fazer opção muito clara quanto ao problema siderúrgico nacional: suprir a produção apenas de subsídios nacionais. Em outras palavras, prescindir de apoio financeiro e de qualquer outro insumo estrangeiro para a produção do ferro e do aço nacionais.

A discussão assim se impunha por responder a dois elementos específicos, quais sejam: a alimentação dos altos fornos siderúrgicos e o transporte do ferro gusa e do aço produzidos no Brasil. No primeiro caso, quanto à alimentação dos altos fornos, o corpo técnico mineiro argumentava a viabilidade da utilização do coque vegetal, abundante em Minas Gerais, em detrimento do coque mineral, que, para ser consumido em grande quantidade, teria de ser importado. Escolher o coque vegetal era, portanto, na opinião dos emopianos, fazer a opção mais lógica, sendo que

29 “O problema da siderurgia e da exportacão de minério de ferro em alta escala só deverá ser resolvido por capital nacional. Retenhamos o que é nosso. Dentro de nossa pátria é que deve cair a chuva doirada - produto da troca de minério de ferro por metal sonante, chuva que fertilizará nossas finanças, que elevará nosso crédito, nosso câmbio, nosso conceito, que armará nosso exército, que fará ressurgir nossa armada. Somente uma empresa nacional deverá solucionar o problema siderúrgico brasileiro. O Estado Novo, com poderes ilimitados, terá o apoio da massa total dos brasileiros para resolver a questão de modo profundamente nacional. (Janot Pacheco. Conferência realizada na Associação Comercial de Minas. Revista Mineira de Engenharia. Ano 1, no 4. 1938: p. 35)."

${ }^{30}$ Ver Conselho Técnico da Sociedade Mineira de Engenheiros. Siderurgia Nacional e exportação de minério de ferro. Parecer. Ano $1, n^{\circ} 7,1938$. Daqui em diante, quando for citado o referido Parecer, vale esta referência. desligava a produção nacional dos interesses externos. O corpo técnico vinculado ao Governo Federal, entretanto, desacreditava da possibilidade de se utilizar o coque vegetal em larga escala para a implantação da indústria siderúrgica, preferindo o mineral (importado). Na leitura procedida pelo corpo técnico mineiro "A imensa extensão [...] coberta de mata virgem e densa, próxima das melhores jazidas de minério de ferro e ao lado das melhores cachoeiras do Rio Doce, dá-nos a convicção de que ali se encontra a solução para o futuro de nossa siderurgia” (Vianna, 1938).

Eleger o carvão vegetal como fonte de alimentação dos altos fornos coincidia com a escolha de Minas como região primordial para a implantação da grande siderurgia nacional porque também, segundo os estudos dos engenheiros mineiros, o minério de ferro de Minas Gerais era um dos melhores do mundo. Reduzi-lo, regionalmente, a ferro gusa e, posteriormente, beneficiá-lo (o transformando em aço), com carvão vegetal (abundante na região) era a base do projeto siderúrgico do corpo técnico mineiro.

Respondia-se, assim, a três problemas imediatos. O primeiro, relativo ao caso Itabira Iron. Se iria se reduzir o minério de ferro em Minas Gerais, tornava-se dispensável a utilização da estrada de ferro da empresa, que acabava por levar o minério da região (de excelente qualidade) para ser beneficiado no exterior. O segundo, relativo ao coque e sua decorrente importação. Ao ser escolhido o coque vegetal, já que se comprovava por meio de estudos publicados pela mesma Revista seu enorme potencial, Minas deveria ser o local de implantação do projeto, sendo que possuía incontáveis reservas florestais aptas a tornarem-se carvão. E, por fim, resolver-se-ia a longa contenda do "atraso" econômico regional, transformando Minas Gerais no polo nacional da grande siderurgia.

Dessa forma, a argumentação do corpo técnico mineiro orbitou essas três proposições que, trabalhadas conjuntamente, representavam a parte principal do projeto do grupo para a questão da grande siderurgia nacional. Profundamente nacionalista, o referido projeto estampou as páginas da 
Revista Mineira de Engenharia, ora por meio de artigos isolados ora por meio de um Parecer, com mais de cinquenta páginas, publicado em nome da Sociedade Mineira de Engenheiros, cuja presidência estava em mãos do emopiano Honório Hermeto. ${ }^{31}$ O Parecer, documento publicado em 1938 e entregue ao ministro da Viação e Obras Públicas e ao governador do estado de Minas Gerais, Benedito Valadares, trazia a indicação desse estado como o nascedouro e o berço futuro da grande siderurgia, ideia formulada como a única hipótese séria a ser aventada pelo poder público central no que toca à solução do problema siderúrgico brasileiro. No que se refere ao seu nascimento, diz o Parecer que "toda a história da siderurgia brasileira é a história da siderurgia mineira" (Parecer, p.4). Já no tocante à sua importância futura para a questão, a argumentação exporia que

O vale do Rio Doce é um dos melhores locais para a instalação de usinas siderúrgicas [...] A quantidade extraordinária dos melhores minérios de ferro do mundo, numa região ainda em boa parte coberta de matas e dotada de abundante força hidráulica, são as condições essenciais que recomendam a extensa zona (Parecer, p.9).

O Parecer incluía, por conseguinte, dezoito sugestões ao Governo Central de como organizar o desenvolvimento siderúrgico nacional (rompendo o contrato com a Itabira Iron), onde implantar a indústria siderúrgica, como alimentá-la e, inclusive, como financiá-la prescindindo do capital estrangeiro, via Banco do Brasil e por meio de sistematização de projeto estatal de exportação de minério de ferro.

Carvalho (2002) aponta, consequentemente, que o Parecer foi devidamente censurado, sendo proibida sua publicação em território nacional, em que pese sua publicação em páginas da Revista Mineira de Engenharia, com a indicação de que

${ }^{31} \mathrm{Em}$ que pese creditar aos emopianos a guarda do referido projeto, não podemos negligenciar que, mesmo entre o grupo, havia quem dele discordasse. É o caso do professor Emídio Ferreira da Silva que, em discurso comemorativo à formatura da turma de engenheiros de minas de 1935, pela EMOP, afirmará que "Sou partidário da livre exportação do minério; ainda não pude me convencer, dada a nossa reserva em minérios de ferro, que a saída desta riqueza deixe um vácuo em nosso Paiz, e venha um dia, produzir escassez de matéria-prima. [...

O carvão de madeira não parece prestar-se a uma indústria de vulto razoável.“ (REM, n ${ }^{\circ} 1$, ano 1, 1936: p. 31).
A Revista Mineira de Engenharia, desejando a maior divulgacão possível do parecer da Sociedade Mineira de Engenheiros sobre a Siderurgia Nacional e a exportação do Minério de Ferro em todo o Brasil, coloca à margem o direito de exclusividade de sua publicação, permitindo que outras revistas e jornais façam sua reprodução, mas só integralmente, visto a publicação parcelada constituir objeto de interpretação errônea sobre o sentido fundamental da obra em apreço que só pode ser apreciada e compreendida convenientemente, em conjunto (Parecer, p.50).

Sendo intenção da Sociedade Mineira de Engenheiros divulgar seu Parecer, e suas ideias em decorrência, foi desejo do Governo Vargas (ou ao menos do corpo técnico a ele vinculado) renegálo. Não convinha àqueles que, formados na Politécnica fluminense, com outras propostas já em vias de efetivação, ter de dar à sociedade a explicação pública de por que recusavam coque nacional em nome do estrangeiro, ou mesmo por que optavam pelo Rio de Janeiro, sendo que o minério de melhor qualidade era o de Minas Gerais. Evidentemente, outras questões estavam também sendo aventadas, além das sugeridas pelo corpo técnico de Minas, que levavam os técnicos ligados ao poder federal a desenvolver planificação própria.

Fato é que, em 1941, após estudos da Comissão Preparatória do Projeto Siderúrgico, presidida pelo ex-aluno da Escola Politécnica do Rio de Janeiro, Edmundo de Macedo de Soares e Silva, a grande siderurgia nacional começa a se instalar no Rio de Janeiro, reduzindo minério de ferro com coque estrangeiro e, saliente-se, bancada em grande parte por capital norte-americano, por meio de empréstimo de 20 milhões de dólares concedido pelo Eximbank (empréstimo, inclusive, negociado pelo próprio Edmundo Macedo). ${ }^{32}$ Era o início da Companhia Siderúrgica Nacional.

A perda do projeto siderúrgico nacional foi, para a elite técnica mineira, fator importante no que concerne à sua disposição frente à dianteira decisória regional (Diniz, 1981; Dulci, 1999). Aos emopianos, principais articuladores da referida estratégia, pouco espaço decisório sobrou quando, outra vez, Minas Gerais necessitou reordenar

${ }^{32}$ Sobre a Companhia Siderúrgica Nacional, ver Vargas (1994). 
suas preocupações visando à superação do atraso econômico.

Independentemente de derrotados na "queda-de-braço" pela elite técnica federal, demonstraram enorme senso político, utilizando a tribuna mais visível que possuíam (a Sociedade e sua Revista) para, politicamente, oferecer argumentos e promover o debate em torno do tema. Paradoxalmente, aqueles que defendiam o afastamento das contendas políticas ${ }^{33}$ foram delas importantes atores quando se fez conveniente.

Cabe aqui ressaltar, conclusivamente, que o discurso nacionalista e intervencionista defendido pelos emopianos, em linhas gerais, não foi formulado de última hora, na necessidade de se fomentar um arrazoado em que a defesa de Minas e do Estado como focos do projeto siderúrgico fosse primordial. Antes, responde às próprias influências da Escola de Minas. Desde o princípio de suas atividades, a EMOP dedicou-se, como já apontado em outro momento deste texto, à constituição de projeto de desenvolvimento econômico nacional. Foi pensando nisso e nas necessidades específicas do desenvolvimento regional que os técnicos graduados pela Escola se dedicaram à formulação de projeto comum e eminentemente nacionalista.

O fato de terem sido “derrotados", se é que se pode caracterizar dessa forma o processo aqui resumido, não reduz o lugar dos emopianos no quadro geral que se há de montar sobre o período sublinhado neste artigo. Mas os tornam exemplares no que tange às formas de uma categoria específica interagir com o Estado, quando inserida nele, principalmente se inspirada por formação muito marcante e eivada de sentido que se pretende comum.

\footnotetext{
${ }^{33}$ Como Israel Pinheiro defendeu, quando de sua posse em 1933 na Secretaria de Agricultura, "O problema político brasileiro ainda será, portanto, o problema do homem. E teremos assim, na vida pública, de nos movimentar dentro da "eterna contenda dos homens e dos partidos. Mas nesta luta devemos nos conduzir com elevação, sinceridade e desprendimentos, sem mobilizar as condenáveis forças dos interesses e das ambições pessoais [grifo nosso] (...) E os governos devem, com a força que lhes é inerente, manter bem alto o princípio da autoridade." Estado de Minas 16/01/1934 (extraído de Roque, 1999).
}

\section{OS ESAVIANOSE O DESENVOLVIMENTO: melhorar o homem, o animal e a semente}

O tema do ensino agrícola já estava presente nos projetos dos políticos mineiros antes da Primeira República, ${ }^{34}$ mas somente a partir do I Congresso Agrícola, Industrial e Comercial houve mobilização de recursos públicos, de forma sistemática, a fim de que fossem concretizadas agências e agentes que lhe dessem forma concreta (Faria, 1992). Inicialmente, as atenções voltaram-se para a questão da força de trabalho no campo, ponto que, no período, inquietava os produtores, graças às repercussões da transição do trabalho escravo para o trabalho livre (Faria Filho, 1990). Os produtores passaram a demandar soluções estatais que pudessem alterar tal panorama, ea educação emergiu como uma das possibilidades de retenção e organização da mão de obra no meio rural (Faria Filho, 1990). Para que pudesse cumprir tais funções, o ensino agrícola foi estruturado em dois níveis: um ensino profissional realizado em escolas, e outro de instrução prática voltado para trabalhadores adultos (Faria, 1992). Somente após tais iniciativas foi que as atenções se voltaram para o ensino médio e o superior. As ações realizadas por Arthur Bernardes, durante sua gestão como presidente do estado, marcaram o início dessa outra etapa. Desse modo, entre 1918 e 1922, moveu recursos para incentivar o ensino médio e o superior agrícola, ambos, até então, deixados nas mãos da iniciativa privada.

No que toca ao ensino superior, portanto, a novidade trazida pela iniciativa de Arthur Bernardes não foi a sua introdução no estado, uma vez que já havia escolas privadas que desempenhavam essa função, mas o fato de a primeira iniciativa estatal "ter sido planejada como base para um grande salto para a modernização do campo, pretendida pelo projeto de diversificação produtiva.” (Dulci, 1999, p.52). Destarte, a construção da

${ }^{34}$ Exemplo bastante ilustrativo é o livro de Francisco Iglésias (1958): Política Econômica do Governo Provincial Mineiro, 1835/1889. Notadamente, a parte dedicada ao ensino agrícola expressa a preocupação por parte dos presidentes de província de Minas Gerais em promover o aprimoramento da formação técnica dos produtores rurais. 
Escola Superior de Agronomia e Veterinária (ESAV), na cidade de Viçosa, revela traços importantes para a modernização que a elite mineira da $1^{\mathrm{a}}$ República almejava, uma vez que "a escola estava ancorada numa premissa de ordem e mudança e através de lá se tentou introduzir um novo paradigma de ensino agrícola” (Idem, 1999, p. 52). Para Daniel Serapião de Carvalho, que ocupava a pasta da Secretária de Agricultura de Minas Gerais durante a construção da Escola, a ESAV teria sido

... presenteada ao Brasil como monumento de uma ideia nova, capaz de transformar os nossos processos empíricos de exploração da terra em verdadeira agricultura, com a utilização racional do solo para a produção agrícola e pastoril (Carvalho, 1951, p.233).

Compondo o projeto de diversificação da economia mineira, foi criada por Arthur Bernardes uma escola estatal de ensino superior agrícola, a ESAV. Dava-se início, a partir de então, na Zona da Mata mineira, a um plano que propunha construir uma instituição de ensino agrícola, teórico e prático.

As funções de norteadora do desenvolvimento da agricultura mineira e de definidora dos novos rumos para a estrutura agropecuária do estado foram externadas por Arthur Bernardes em discurso proferido durante cerimônia de formatura da Escola. Ele realçou o desígnio imputado à instituição, caracterizando-a como marco, um “divisor de águas”, de passagem para uma época moderna e superação de outra, de atraso:

Fincávamos aqui um marco assinalado, por que divisório de duas épocas distintas na vida agrícola de um dos maiores Estados da Federação: a que vinha dos primórdios da nacionalidade, caracterizada pelo primitivismo agrícola, e outra que se iniciava com a implantação de novos processos de trabalhar a terra e cuidar das plantas, das árvores e dos animais. Inspirava-nos então, como ainda hoje, o objetivo de tornar o trabalho mais produtivo com menor esforço do homem..$^{35}$

O arquétipo institucional seguido pela instituição foi os dos Land Grant Colleges norte-ame-

${ }^{35}$ Discurso proferido por Arthur Bernardes no ano de 1952, durante a cerimônia de colação de grau dos engenheiros agrônomos, na qual foi o paraninfo (Borges, 2000, p.27). ricanos, nos quais o ensino, a pesquisa e a extensão desenvolviam-se de forma imbricada. Foi contratado especialista norte-americano, ${ }^{36}$ Peter Henry Rolfs, para amparar com modelo institucional os planos da elite mineira, desejosa de escola que embasasse projeto de desenvolvimento regional. Em 28 de agosto de 1926, aconteceu a solenidade oficial de inauguração da ESAV. O evento contou com considerável parcela da elite política de Minas Gerais: Arthur Bernardes, então presidente do Brasil, o presidente de Minas Gerais, Fernando Mello Vianna, e o secretário de agricultura, Daniel Serapião de Carvalho (Borges, 2000, p.8). Nascia em Minas Gerais, pelas mãos da elite política, em meio à crise da agricultura regional, a primeira escola estadual de ensino superior agrícola - local que deveria servir, a partir de então, de polo irradiador de tecnologias para o setor agropecuário do estado. Dela deveriam partir os profissionais com a função

... de redimir a terra santa do Brasil que os processos pré-colombianos, o fogo e nomadismo dos índios, o sangue e os abusões dos negros, os erros seculares da cobiça e da ignorância poluíram, degradaram, esterilizaram em largas extensões (Carvalho, 1951, p.242).

A neófita Escola Superior de Agricultura e Veterinária, concebida graças a projeto específico e notoriamente identificada com um grupo político ${ }^{37}$

${ }^{36}$ Arthur Bernardes pediu ao embaixador brasileiro nos Estados Unidos, José Cochrane, que indicasse especialista capaz de fundar, organizar e dirigir uma Escola Superior de Agricultura moderna em Minas Gerais. Duas indicações precederam a sugestão de Peter Henry Rolfs; a do Dr. Eugene Davenport, que já havia lecionado no estado de São Paulo e a do Dr. Romel, especialista em zootecnia. Ambos declinaram o convite, o primeiro argumentando que a senilidade o impedia de tamanha empreitada, e o segundo a impossibilidade de interrupção de suas pesquisas. P.H. Rolfs foi o terceiro a ser indicado e acabou por aceitar o convite, embarcando em janeiro de 1921 para o Brasil. Já antes de deixar a Flórida, tinha iniciado o estudo da agricultura mineira em contato com quatro brasileiros que estudavam na Universidade da Flórida. Por meio de conferências com o governador do estado e outros educadores, acertaram que a futura escola deveria tanto ter como objetivo final servir à mocidade rural do estado, como não se restringir a um estabelecimento de instrução mas, sim, para orientar todos que desejassem (Barbosa, 2004).

${ }^{37}$ Artur Bernardes, mesmo sendo uma das figuras mais proeminentes do Partido Republicano Mineiro (PRM), foi apoiador do movimento político que desencadeou a Revolução de 1930. Entretanto, após a vitória do movimento, em Minas Gerais, a situação caracterizou-se pelo embate de dois grupos, ambos de feição oligárquica. De 
e um setor econômico, teve sua primeira turma de engenheiros-agrônomos graduada em 1931, um ano após a vitória da Revolução de Outubro. Desafortunadamente, quando o movimento de ideias e projetos, típico da Primeira República, sofreu forte inflexão em virtude da conjuntura inaugurada pela Revolução de 1930. Momento, inclusive, em que as elites agrárias não mais usufruiriam de exclusividade na arena política (Martins, 1980), perdendo, consequentemente, o monopólio na consecução de seus projetos. Se, no contexto específico da República Velha, estava reservada à ESAV a função de intervir e dinamizar a complexa estrutura agro-pastoril de Minas, por meio dos diletos "gestores do mundo rural”, a conjuntura inaugurada no pós-1930 incidiu decisivamente sobre tal perspectiva. Assim, se, por um lado, o contexto nacional significou novos caminhos para atuação definitiva dos profissionais possuidores de conhecimentos que pudessem gerenciar as novas demandas do setor urbano-industrial, com repercussões relativamente menores para o engenheiro-agrônomo esaviano, no contexto regional, por outro lado, e no mesmo período, a política de desenvolvimento econômico adotada pelo Governo de Minas Gerais privilegiava a diversificação econômica, com a agricultura ocupando lugar de destaque (Dulci, 1999).

Levando em conta o rearranjo político decorrente da Revolução de Outubro (Fausto, 1981), a rearticulação da economia imposta pela crise de 1929 (Cohn, 1974) e os contornos da política econômica regional, é importante identificar como os esavianos reagiram a essa somatória de acontecimentos que incidiram sobre as funções que, inicialmente, lhes haviam sido reservadas. Análise dos artigos de divulgação técnico-científicos das revis-

um lado, aglutinavam-se aqueles mais identificados com o PRM e liderados por Artur Bernardes. De outro, aqueles apoiados por Olegário Maciel, então governador do estado e que realizava forte campanha anti-bernardista. Desdobramentos desse embate conduziram Artur Bernardes a apoiar a causa paulista durante a Revolução de 1932. Com a derrota da Revolução Constitucionalista, em 23/09/1932, Artur Bernardes foi preso em Araponga, cidade próxima a Viçosa, seu reduto político, e embarcado em um trem para o Rio de Janeiro, sendo, em seguida, enviado para o exílio, de onde retornou após a anistia aos revolucionários, decretada por Getúlio Vargas (Abreu, 2001, p. 627-638). tas Ceres e Seiva ${ }^{38}$ foi o caminho traçado. Nesse material, estão presentes indicações do diagnóstico que o grupo profissional reunido na ESAV realizou sobre a estrutura agropecuária mineira, detectando problemas que acreditavam ser mais urgentes e as estratégias que supunham pertinentes para superá-los. Esses dois componentes do discurso - diagnóstico e soluções - dão indicações dos meios escolhidos por esse grupo para a promoção da modernização da agricultura.

O primeiro exemplar da revista Ceres foi publicado em julho de 1939, resultando da iniciativa do Clube Ceres - associação cultural e técnico-científica, fundada na década de 1930 pelo professor norte-americano J. B. Griffing, que congregava os professores da ESAV. A revista se autodesignava não só como instrumento de divulgação técnico-científica da instituição, mas, também, "expressão e esteio dos seus objetivos". Criada, portanto, com a finalidade de amparar a ESAV em seu o triplo objetivo, "melhorar o homem, o animal e a semente", assim registrava que a

... complexa missão que a Escola se impusera exigia imprescindível e poderosa colaboração da Imprensa que, pela palavra impressa, multiplicasse a sua voz evangelizadora do meio rural e a levasse a todos os recantos da pátria brasileira, onde quer que houvesse uma preocupação pelos problemas agropecuários e onde quer que existisse um braço erguido no abençoado gesto do semeador (Ceres, ano 1, $\mathrm{n}^{\mathrm{o}} 1,1939, \mathrm{p} .2$ ).

No primeiro editorial da revista, qualificada “cem por cento esaviana”, são justificados os motivos de sua criação, nos quais são expostos objetivos que ultrapassavam o simples papel de órgão de vulgarização de conhecimentos técnico-científicos:

${ }^{38}$ As revistas Ceres e Seiva são os dois periódicos mais importantes da Escola. A revista Ceres estava sob a responsabilidade do corpo docente da ESAV, enquanto a Seiva estava sob a dos discentes. Ambas as revistas começaram a ser editadas no final da década de 1930. As impressões aqui expostas dizem respeito às publicações editadas até o ano de 1948. O recorte se justifica em virtude da transformação da ESAV em Universidade Rural de Minas Gerais (UREMG) em 1948, mudança que causou consideráveis alterações na referida Escola. Se, por um lado, o tardio início da publicação das revistas não permite que acompanhemos reações por toda a década, por outro, elas datam de momento em que mudanças políticas e econômicas levadas a cabo pelo Governo Getúlio Vargas já estão bem mais definidas. 
Os princípios que norteiam a ação da Esçola constituem o programa [da revista Ceres]. É por isso que em suas páginas vamos encontrar, ao lado dos trabalhos científicos originais, abundante texto de divulgação enfeixando conhecimentos práticos, de aplicação imediata às necessidades da vida quotidiana do agricultor e de todos que estão em contato com o mundo rural. Por ora é esta a organização que mais se adapta ao meio agrícola mineiro (Ceres, ano 1, nº 1, 1939, p.3).

Leitura extensiva dos artigos sugere que, para os docentes da Escola, ${ }^{39}$ o problema decisivo da estrutura agropecuária se encontrava na persistência da utilização de métodos tradicionais por parte dos agricultores, pouco racionais em termos econômicos e produtivos. Nessa perspectiva, o problema residia na contumácia dos agricultores em manter o tradicional, e eles, munidos do conhecimento científico, ofereciam as soluções modernas para produtores e produção. As únicas capazes, aliás, de construir um setor agrícola forte e dinâmico.

A mecanização da produção, o melhoramento das raças, a seleção de sementes, a conservação e restauração do solo e a adoção por parte dos agricultores de formas racionais de administração de suas propriedades foram, em linhas gerais, o antídoto aconselhado para agricultura notadamente "atrasada" e "rotinizada". No entanto, a apreciação do material sugere que, dentre os fatores citados, a mecanização do processo produtivo (tratores de tração mecânica) é o ponto mais recorrente do discurso dos docentes esavianos e, para eles, a sua incorporação era imperiosa, uma vez que "agricultura desenvolvida e comercializada é agricultura mecanizada" (Ceres, ${ }^{\circ}$ 7, ano 1, 1940, p.64). Embora os argumentos acerca da inclusão de tratores sofressem variação discursiva, a crença em sua necessidade era constante.

O homem rural foi também alvo direto dos intentos dos docentes esavianos, já que ele precisaria estar apto para incorporar as inovações que lhe eram apresentadas. Portanto, assim como a

${ }^{39}$ Falamos em docentes da Escola em virtude da predominância quantitativa de colaboradores, professores e exprofessores da ESAV, salvo algumas participações de pesquisadores e professores de outras instituições (Barbosa, 2004). produção, os produtores deveriam ser "melhorados". As tentativas de aprimorar as condições fisiológicas são exemplares, posto que "um homem mal nutrido" não teria condições de compreender e utilizar os métodos modernos. Para o docente Raimundo Lopes de Faria, médico e professor da disciplina de Higiene, o homem rural se encontrava "mal alimentado", graças, principalmente, à carência de orientação. Para ele, o "roceiro é o que mais come e menos se alimenta" (Ceres, $\mathrm{n}^{\circ} 12$, ano 2, 1941, p.61). Continuando, enfatiza que o homem do campo deixava de aproveitar os alimentos de sua propriedade, encontrados "na porta de sua casa” (Ceres, $\mathrm{n}^{\circ} 12$, ano 2, 1941, p.63), para buscar outros alimentos nas cidades. Acrescenta, por fim, que os homens do campo adquiriam, encantados pelas ofertas urbanas, produtos industrializados e caros, acreditando que assim estariam a realizar adequada nutrição.

Outra atitude muito ilustrativa das incursões esavianas para orientar o produtor é a tentativa de difusão de nova mentalidade administrativa. A falta de utilização de "contabilidade rural" também era considerada grande responsável pelo atraso das unidades produtivas. Tal assertiva é justificada em virtude de "averiguação", realizada pelo professor do Departamento de Economia Rural, Erly Dias Brandão (Ceres, ano 1, n 7, 1940). O referido professor chega a essa "constatação" por meio de questionários distribuídos a agricultores, durante evento realizado pela Escola. Após análise das respostas, concluiu que, "das centenas de questionários distribuídos”, poucas dezenas de produtores haviam declarado possuir algum tipo de controle contábil de seus negócios, fato que, aos olhos do docente, impossibilitava domínio seguro acerca dos lucros e prejuízos das propriedades. Brandão relata ainda que buscou criar, dentro da ESAV, medidas que contornassem tal realidade, uma vez que a contabilidade desempenharia papel capital na direção das fazendas. Ao aprender técnicas administrativas, o agricultor galgaria um passo decisivo em direção à posição de "administrador rural".

Paradoxalmente, as questões mão de obra e 
êxodo rural ${ }^{40}$ pouco figuram nos artigos desse periódico, sendo abordadas implicitamente quando o tema central é a mecanização, uma vez que suas repercussões seriam atenuadas quando essa tecnologia fosse adotada. Dessa forma, ao pontuar a necessidade de tração mecânica, ou mesmo animal, realça-se que um cultivo realizado por enxadas seria moroso, caro e imperfeito e ainda exigiria volumoso número de braços para seu manejo. Carências essas que, mesmo se supridas, proporcionariam cultivo imperfeito e concluído fora do tempo ideal (Ceres, ano 1, $\mathrm{n}^{\circ} 2,1939$ ).

Os artigos dedicados aos cuidados e melhoramento dos animais são numericamente inferiores aos referentes à agricultura. ${ }^{41}$ No entanto, no periódico, estão presentes aconselhamentos sobre as mais variadas técnicas destinadas à criação de bovinos, suínos, galináceos, dentre outros. Divulgaram-se, na maioria das vezes de forma detalhada, técnicas de melhoramento de raças, cuidados e tratamentos de doenças, alimentação e informações para construção dos locais mais apropriados para seus respectivos manejos.

De um modo geral, a revista Ceres foi um periódico que não se limitou apenas a divulgar artigos técnico-científicos, como também serviu de veículo de construção de problemas a serem resolvidos e de delimitação de espaços de atuação profissional dos esavianos. Destarte, em meio à divulgação de "conhecimentos modernos", estava presente uma atitude de constante desqualificação dos métodos de que, tradicionalmente, faziam uso os agricultores mineiros. Por meio da revista, os profissionais da agricultura, ancorados na academia, criaram "oportunidade para combater tenazmente o que acreditavam ser falsas ideias de muito de nossos fazendeiros". Ideias que, para os esavianos,

${ }^{40} \mathrm{O}$ movimento emigratório de Minas Gerais para outros estados atingirá grandes proporções no transcurso do século XX (Wirth, 1982), transformando-se em problema debatido pela elite política, econômica e técnica. Assim, as Comissões Fundamentais do I CAIC citavam esse problema, bem como a Revista Mineira de Engenharia também o tratava, mesmo que tangencialmente e relacionando-a à necessidade de industrialização para conter a saída dos mineiros.

${ }^{41}$ Quanto ao perfil temático da revista no período, dos 331 artigos selecionados, 187 foram dedicados à seção de agricultura, 109 à de veterinária e 32 às industrias rurais. seriam responsáveis pela sustentação de realidade agropastoril marcada pelo atraso. Assim, a cada nova técnica ou tecnologia, minuciosamente noticiada, estava implícita a necessidade da presença de um engenheiro-agrônomo. Mesmo porque, oculta em manejo apresentado de forma simplificada, estava a necessidade de uma primeira demonstração de utilização, que preferencialmente deveria ser realizada pelos profissionais da agricultura.

A primeira edição da revista $\operatorname{Seiva}^{42}$ foi publicada em agosto de 1940, quando se externou o desejo de

... estar sempre em contato com os que se dedicam às lides rurais, Seiva, desde a sua fundação, vem trabalhando pelo melhoramento das condições do fazendeiro, quer levando-lhe artigos de utilidade prática, quer amenizando-lhe as horas de melancolia através de contos e crônicas leves. Como seu programa é batalhar, dentro de suas possibilidades, pelo engrandecimento da Agricultura Nacional, Seiva entrega aos interessados esta nova seção [de consultas], que bem demonstra a utilidade dessa atitude de compreensão que a ESAV mantém para com os problemas do homem do campo (Seiva, ano 1, $\mathrm{n}^{\mathrm{o}} 1,1940$ ).

A parte da revista Seiva dedicada aos artigos técnico-científicos é bastante reduzida, principalmente se comparada à da revista Ceres. No entanto, nela também está presente, como em sua congênere, a vontade expressa de superar o "atraso" que acreditavam vigorar na agricultura. Nos artigos, os alunos também sugeririam os seus meios e seus motivos para racionalizar as culturas vegetal e animal. Ainda assim, não existiam somente semelhanças entre os periódicos. Em linhas gerais, pode-se sublinhar uma diferença expressiva entre as revistas Seiva e Ceres: a primeira possui maior amplitude e heterogeneidade temática, e nela encontramos, de forma muito mais constante e direta, autorreferências aos alunos e professores que constituíam o grupo de profissionais da Escola. Alusões explícitas aos seus predicados positi-

${ }^{42}$ Como no caso da revista Ceres, esse periódico teve sustentação predominantemente endógena, tendo como principais colaboradores seus próprios alunos e professores, salvo raras exceções. Quanto ao perfil temático dos 57 artigos selecionados, 28 versaram sobre agricultura, 15 sobre veterinária e 14 sobre indústrias rurais e 6 que não couberam nas classificações anteriores (Barbosa, 2004). 
vos, suas fotos e seus endereços residenciais foram constantes no período analisado. Portanto, na Seiva, os dois elementos "reeducação e engenheiros-agrônomos” foram explicitados e relacionados de forma muito mais incisiva que na Ceres.

A defesa da necessidade da reeducação do homem rural e a sua vinculação direta com os nomes, rostos e endereço dos profissionais que poderiam realizá-la é mais aberta. Quase como regra, na maioria dos volumes da Seiva, páginas eram dedicadas à divulgação do "aço que saía da forja ESAV", ${ }^{43}$ seguida das fotos dos respectivos formandos do ano. Referências e homenagens biográficas aos professores da casa, compostas com a divulgação de suas fotos, também eram comuns na revista. Estratégia de inserção profissional, via autodivulgação e autorreconhecimento, características que não são observadas na publicação dos docentes.

No que toca às semelhanças, nos artigos técnico-científicos selecionados, reedita-se padrão de evidenciar atrasos e prescrever "soluções modernas”. Essa tendência pode ser apreendida, por exemplo, no artigo Quantos ovos a sua galinha deve pôr para que seu galinheiro dê lucro, do aluno Jac Benbassat. A introdução da matéria começa com advertência que ressalta que o título de seu artigo deveria ser indagação realizada cotidianamente por todo avicultor, já que "os registros da postura, de consumo de alimento e outros mais, certamente toda criação racional possue", e que o uso de tais informações serviriam ao criador como a bússola ao navegante (Seiva, ano 3, $\mathrm{n}^{\circ}$ 12, 1943, p.4).

Dois temas que figuram de forma mais direta na Seiva que em Ceres são o êxodo rural e o problema da mão de obra. Na Ceres, eles são colateralmente mencionados nos artigos que tratam da mecanização, ou ainda de maneira superficial como, por exemplo, quando defendia a necessidade de "embelezamento das unidades produtivas" como medida para a fixação do homem no campo (Ceres, ano 1, $n^{\circ} 3$, 1939). $O$ artigo, escrito

${ }^{4}$ Essa expressão "o aço que sai de nossas forjas” foi, durante muitos anos, utilizada por Edgar de Vasconcelos para introduzir as fotos dos formandos em engenharia-agronômica. pelo aluno Otávio A. Moreira (Seiva, ano 6, n² 23, 1946), busca revelar os motivos que explicariam a saída do homem das zonas rurais. Ele alega que o progresso crescente, materializado na criação de escolas nas fazendas, no recrutamento militar e na abertura de novas estradas, acabava levando o homem analfabeto e atrasado para as cidades, já que tais mudanças proporcionavam alargamento de percepção da realidade, levando o caboclo a sentir que a cidade lhe oferecia vida melhor e mais confortável que a do campo. Em contrapartida, os caboclos perceberiam que a vida que levavam na roça era repleta de restrições, tendo como companheiras as verminoses e a malária, agravadas pela falta de assistência médica. Figuram nessa revista, portanto, também questões sociais e não apenas técnicas.

O padrão de divulgação de técnicas e tecnologias para o processo produtivo também permanece inalterado nesse periódico como, por exemplo, pode ser observado no artigo de Alberto Campos Silva, intitulado Erosão e Conservação do Solo (Seiva, ano 6, no 21, 1945). Nele é apresentada uma análise completa acerca da erosão e dos métodos para que tal degradação fosse evitada ou revertida. Segundo o autor, a erosão estava sob a responsabilidade direta do produtor que, em sua "incúria dos homens, no afã de retirar do solo o máximo de sua capacidade [...] cooperou grandemente com a natureza para o surgimento de um grande fator de miséria - a erosão." (Seiva, ano $\left.6, n^{\circ} 21,1945\right)$. Conclui que “... basta que façamos agricultura, que tenhamos terras em uso constante e intensivo, para termos que as proteger e conservar." (Seiva, ano 6, $\left.\mathrm{n}^{0} 21,1945\right)$. Afora as peculiaridades dessa revista, que não chegam a conformar agudas diferenças, ela propagou as ideias, percepções e os instrumentos de intervenção compartilhados pelos graduandos da Escola, lançando, por sua vez, uma campanha mais explícita de tentativa de inserção de seus profissionais no mundo rural, trabalhando, como a Ceres, a necessidade da reeducação do homem rural e enfatizando, para tanto, o atraso que o "consumia". 


\section{CONSIDERAÇÕES FINAIS}

Pensar as múltiplas transformações ocorridas na década de 1930 e posteriores não é procedimento simples. Procuramos, aqui, tentar analisálas a partir de questões regionais, relacionadas à emergência de uma categoria profissional muito distinta às arenas públicas de decisão (os engenheiros, agrônomos ou civis, mineralogistas e metalurgistas) e determinados aspectos de seus projetos. E, substancialmente, discutir o processo abordado (e a participação do referido grupo) por meio dos seus construtos discursivos, devidamente registrados em publicações da categoria.

Independentemente de serem voltadas para o universo rural ou para o urbano, se direcionadas para a agricultura ou para a siderurgia, as preocupações dos engenheiros de Minas Gerais, a partir da década de 1930, fundamentalmente, estampam as páginas das suas publicações específicas. Possuem, no geral, um fio condutor que perpassa tanto o pensamento mais urbano dos emopianos (voltados, como vimos, para as questões siderúrgicas), como a leitura do espaço rural dos esavianos. Assim, o que fornece a unidade subjetiva ao discurso de ambos os grupos é o atraso. Ou, antes, essa unidade se origina como força motriz impulsionadora da superação do atraso que embaraça o estado de Minas, rumo ao seu desenvolvimento econômico. Superá-lo, portanto, representa, na leitura da categoria profissional dos engenheiros de Minas Gerais, naquele momento específico, derrubar a barreira que se punha a travar o estado desde, ao menos, o final do século XIX.

Que havia diferença de escopo nos projetos de ambos os grupos, sendo o siderúrgico vertical (Estado) e concentrado (grande capital) e o agrícola horizontal (produtor rural) e desconcentrado (produção agrícola em geral), a observação acerca do conteúdo dos artigos publicados pelas revistas filiadas aos técnicos em questão deixa evidente. Mas essa diferença apenas abruma a profunda relação estabelecida pelos grupos, com uma noção que, grau a grau, ganhava intensidade regionalmente: a intervenção, pelo poder público, como provedora do desenvolvimento econômico regional.
É de se notar, contudo, que ambos os projetos, ao buscar a suplantação do atraso relativo da economia mineira, não consigam transpor a realidade de um quadro econômico marcado pela posição periférica em relação ao polo (São Paulo) a que se pretende equiparar. Modernizar uma agricultura compreendida como tradicional ou possibilitar a modernização industrial do estado de Minas Gerais, de acordo com os projetos em tela, não rompe efetivamente com uma realidade em que a economia mineira desempenhava papel subsidiário ao desenvolvimento econômico de estados vizinhos. Assim, paradoxalmente, o sucesso desses projetos tenderia a constituir parque industrial cuja produção primordial fosse a de bens intermediários e a fomentar setor agrícola que, no geral, conquanto mais moderno, não alcança o desenvolvimento capitalista da agricultura paulista. Curiosamente, é, portanto, uma agenda que repõe o atraso relativo no médio prazo.

Não obstante - seja formulando projeto de ação coletiva a ser encampado pelo Estado, caso específico dos emopianos, ou projeto de intervenção individual relacionado diretamente com o homem do campo, caso próprio dos esavianos, a matriz que informa essa elite técnica é, primordialmente, a crença na razão científica, propulsora de uma prática moderna.Éa emergência do moderno, contra o atraso. E esses homens se tornaram artífices do primeiro, em oposição ao segundo. Nesse sentido, o ideário que tornarão público por meio das revistas técnicas se compõe da exposição de suas competências e habilidades no trato com o novo, capaz de superar o antigo e atrasado. Concomitantemente, suas ideias serão as marcas indeléveis da categoria, distinção essa que os diferirá no trato com a esfera pública em relação aos bacharéis e a toda a burocracia na órbita do Estado.

Ao se organizarem dessa maneira, o fazem baseados na crença de terem sido talhados para tanto. Ou melhor, parafraseando-os, foram "forjados gigantes", ${ }^{44}$ recebendo inclusive o "contraste" ${ }^{45}$ ${ }^{44}$ Conforme denominavam a Escola e a si próprios (Barbosa, 2004).

${ }^{45}$ Conforme um ex-aluno de Ouro Preto classificou a formação recebida pelos emopianos de sua Escola (Barbosa, 2003). 
aferidor da qualidade. E esse "contraste" foi formulado pela Escola. Assim, a busca pelo desenvolvimento e, sobretudo, pela reversão das causas de atraso relativo de Minas Gerais não é exclusiva a esses homens. Essa preocupação orienta a ação de ambas as escolas desde suas respectivas fundações. Por exemplo, Gorceix, primeiro diretor da EMOP, tinha para si, de forma muito clara, o valor do conhecimento técnico no desenvolvimento da economia nacional e, no caso específico de Minas, do desenvolvimento da economia regional.

O fio condutor que podemos vislumbrar nesses homens é o mesmo que podemos entrever em suas instituições acadêmicas. Fundadas para ser, cada uma em sua seara específica, grandes centros de excelência, a EMOP e a ESAV podem ser compreendidas, também, como partes de processo mais amplo: o de construção e solidificação de corpo técnico diversificado em suas especializações, plural em suas ações estritamente técnicas, mas singular em sua atuação política, cuja origem pode ser vislumbrada na EMOP.

O élan do corpo técnico mineiro baseou-se, não obstante a especificidade de sua formação, nesse período principalmente, em uma mesma crença: na capacidade de superação do atraso e produção da riqueza regional. E, ao externarem suas posições, os técnicos mineiros, mesmo que por questões distintas e formas características às suas especificidades profissionais, mantiveram bem nítida a postura de negação do atraso em nome do moderno que somente eles poderiam oferecer.

(Recebido para publicação em setembro de 2009)

(Aceito em novembro de 2009)

\section{FONTES DOCUMENTAIS}

Revista Ceres. Viçosa, anos I a IX.

Revista Escola de Minas. Ouro Preto, anos I a XX.

Revista Mineira de Engenharia. Belo Horizonte, anos I a XVIII.

Revista Seiva, Viçosa, anos I a VIII.

\section{REFERÊNCIAS}

A Escola de Minas 1876-1966. Ouro Preto: Escola Federal de Ouro Preto, 1966.

ABREU et al. (Orgs). Dicionário Histórico-Biográfico Brasileiro. Rio de Janeiro: CPDOC, 2001.

BARBOSA, Daniel Henrique Diniz. Os técnicos em ação: os engenheiros de Minas Gerais e as alternativas de desenvolvimento regional (1935-1945). Belo Horizonte: UFMG, Dissertação de Mestrado, 2005.

A EMOP, seus ex-alunos e suas moradias estudantis: elementos de uma tradição inventada. Ouro Preto: UFOP, Monografia de Bacharelado, 2003.

BARBOSA, Lidiany Silva. Roupa nova para a velha senhora agrária: os engenheiros-agrônomos e a modernização do campo em Minas Gerais. Viçosa: UFV, Dissertação de Mestrado, 2004

BARBOSA, Maria Lígia de O. Reconstruindo as Minas e planejando as Gerais; os engenheiros e a constituição dos grupos sociais. São Paulo: Unicamp. Tese de Doutorado. 1993.

BIELSCHOWSKY, Ricardo. Pensamento Econômico Brasileiro. O ciclo ideológico do desenvolvimentismo. $5^{\mathrm{a}}$ edição. Rio de Janeiro: Contraponto, 2000.

BODEA, Miguel. Trabalhismo e Populismo no Rio Grande do Sul. Porto Alegre: UFRGS, 1992.

BORGES, Marcondes et al. A Universidade Federal de Viçosa no Século XX. Viçosa: Editora UFV, 2000.

CARVALHO, Daniel de Serapião de. Estudos e Depoimentos. Belo Horizonte: Impressa Oficial, 1951.

CARVAlHO, J. Murilo de. A Escola de Minas de Ouro Preto. O peso da glória. $2^{\circ}$ edição. Belo Horizonte: Editora UFMG, 2002.

de. A construção da Ordem: A Elite política Imperial. Col. Temas Brasileiros V.4. Brasília: Ed. UnB. 1981.

COELHO, Edmundo Campos. As Profissões Imperiais. Medicina, Engenharia e advocacia no Rio de Janeiro 18221930. São Paulo: Editora Record, 1999

COHN, Gabriel. "Problemas da Industrialização no Século XX”. Em: Mota, Carlos Guilherme (Org.). Brasil em Perspectiva, $5^{\mathrm{a}}$ edição, São Paulo: Difel, 1974.

DIAS, José Luciano de Mattos. "Engenheiros". In: GOMES, Ângela M. de Castro. (Org.) Engenheiros e Economistas: novas elites burocráticas. Rio de Janeiro: FGV, 1994.

DINIZ, C. Campolina. A industrialização mineira após 1930. In: SZMRECSÁNYI, Tamás, SUZIGAN, Wilson (Orgs.). História econômica do Brasil contemporâneo. $2^{\text {a }}$ edição. São Paulo: Hucitec/ABPHE/ Editora da Universidade de São Paulo/ Imprensa Oficial, 2002.

Estado e capital estrangeiro na industrialização mineira. Belo Horizonte: Imprensa da UFMG, 1981.

DULCI, Otávio S. "João Pinheiro e as origens do desenvolvimento mineiro”. Em: GOMES, Ângela de Castro (Org.). Minas e os fundamentos do Brasil moderno. Belo Horizonte: Editora UFMG, 2005.

DULCI, Otávio S. Política e recuperação econômica em Minas Gerais. Belo Horizonte: Editora UFMG, 1999.

FARIA FILHO. Luciano Mendes. "A República do trabalho: a formação do trabalhador-cidadão em Minas Gerais no alvorecer do século XX”. Cadernos do Departamento de Ciência política, $n^{\circ} 8 /$ revista do Departamento de História, $\mathrm{n}^{\circ}$ 10, Belo Horizonte, número conjunto, 1990. 
FARIA, Maria Auxiliadora. A Política da gleba: as classes conservadoras mineiras: discurso e prática na Primeira República. São Paulo: USP, Tese de Doutorado, 1992.

FAUSTO, Bóris. A Revolução de 1930. $7^{\mathrm{a}}$ edição, São Paulo: Brasiliense, 1981.

FIGUEIROA, S. E. de M. As ciências geológicas no Brasil: uma história social e institucional, 1875-1934. São Paulo: Hucitec, 1997.

FONSECA, Pedro Cezar Dutra. Positivismo, trabalhismo, populismo: a ideologia das elites gaúchas. Ensaios FEE, Porto Alegre, (14) 2: 410-421, 1993.

FREITAS, Marcus Vinicius de. Charles Frederick Hartt, um naturalista no Império de D. Pedro II. Belo Horizonte, UFMG, 2002, 282p.

GOMES, Ângela M. de Castro. (Org.) Engenheiros e economistas: novas elites burocráticas. Rio de Janeiro: FGV, 1994.

HOBSBAWM, Eric. A era dos extremos. O breve século XX. São Paulo: Companhia das Letras, 1995.

IGLÉSIAS, Francisco. Política econômica no Governo Provincial Mineiro 1835/1889. Rio de Janeiro: INL, 1958

KATZ, Friedrich. O México: a República Restaurada e o Porfiriato, 1867-1910. Em: BETHELL, Leslie (org.). História da América Latina. De 1870 a 1930. v. 5. São Paulo: Edusp; Imprensa Oficial do Estado; Brasília: Fundação Alexandre de Gusmão, 2002.

KOURY, Lorelau. Ciência e nação: romantismo e história natural na obra de Silva Maia. História, Ciência, Saúde Manguinhos. v. 2, 1998.

KROPF, Simone P. Saber para prever a fim de prover. In: HERSCHMANN, Micael M. e Pereira, Carlos M (Orgs.). $A$ invenção do Brasil moderno -medicina, educação e engenharia nos anos 20-30. RJ: Rocco, 1994.

Saber para prever a fim de prover. Em: HERSCHMANN, Micael M. e Pereira, Carlos M. A invenção do Brasil moderno -medicina, educação e engenharia nos anos 20-30. RJ: Rocco, 1994.
LIMA, M. Rosa de. D. Pedro II e Gorceix. A fundação da Escola de Minas de Ouro Preto. Ouro Preto: Fundação Gorceix, 1977.

LINS, Ivan. História do Positivismo no Brasil. $2^{\mathrm{a}}$ ed. São Paulo: Nacional, 1967.

LOPES, Maria Margaret. O Brasil descobre a pesquisa científica: os museus e as ciências naturais no século XIX. São Paulo, Hucitec, 1997.

Viajando pelo mundo dos museus: diferentes olhares no processo de institucionalizacão das ciências naturais nos museus brasileiros.Imaginário, $n^{\circ} 3$, p. 5978, 1996.

MARTINS, Luciano.A Revolução de 30 e seu significado político. In: A Revolução de 30: Seminário internacional. Brasília: EDUNB, 1980.

MOORE Jr. As origens sociais da ditadura e da democracia. São Paulo: Editora Martins Fontes, 1983.

NOBLE, David. F. El diseño de Estados Unidos. La ciencia la tecnologia y la aparicion del capitalismo monopolistico. Madrid: Centro de Publicaciones del Ministerio de Trabajo y Seguridad Social, 1987.

PAULA, João Antonio de. Raízes da modernidade em Minas Gerais. Belo Horizonte: Editora Autêntica, 2000.

ROQUE, Rita Menezes. Os bandeirantes dos tempos modernos. A Escola de Minas de Ouro Preto e o bloco no poder em Minas (1889-1945). Rio de Janeiro: UFF, Dissertação de Mestrado, 1999

SÁ, M. \& DOMINGUES, H. O Museu Nacional e o ensino das ciências naturais no Brasil do século XIX. Revista da SBPC, n.15, 1996

VARGAS, Milton. História da técnica e da tecnologia no Brasil. São Paulo: Unesp, 1994.

Vianna, Fernando Melo. Utilização do carvão vegetal na Indústria Siderúrgica. Revista Mineira de Engenharia. Ano $1, \mathrm{n}^{\circ} 5$ e 6,1938 .

WIRTH, John D. O fiel da balança: Minas Gerais na Federação Brasileira, 1889-1937. Rio de Janeiro: Paz e Terra, 1982 
TECHNICAL ELITES, STATE AND REGIONAL DEVELOPMENT IN MINAS GERAIS DURING VARGAS ADMINISTRATION

\author{
Daniel Diniz Henrique Barbosa \\ Lidiany Silva Barbosa
}

This paper addresses the regional development process initiated in Minas Gerais, with particular emphasis on the participation of regional technical staff throughout the 1930s and 1940s. This is an period of important transformations within the government, especially regarding the role played by ideology and planning practice and State interventionism in the economy, allowing, in the Minas case, the rise of the professional category of engineer to decisionmaking arenas of the State, with repercussions in the preparation and attempt of implementation of projects directed to regional economic development, notably in agriculture and steel making areas. To this end, this text will prioritize two specific groups among this Minas state technical elite: the alumni of the School of Mines of Ouro Preto (in Portuguese, EMOP) and the faculty and students of the College of Agriculture and Veterinary, from Viçosa (in Portuguese, ESAV).

Keywords: technical elites, development, agriculture, steel works, ESAV, EMOP.
LES ÉLITES TECHNIQUES, L'ÉTAT ET LE DÉVELOPPEMENT REGIONAL DANS L'ETAT DE MINAS GERAIS À L'ÉPOQUE DE VARGAS

\author{
Daniel Henrique Barbosa Diniz \\ Lidiany Silva Barbosa
}

Cet article analyse le processus de développement régional qui a commencé dans l'État de Minas Gerais et qui a tout particulièrement mis l'accent sur la participation du personnel technique régional au cours des années 1930 et 1940. Il s'agit d'une période de transformations importantes au sein du gouvernement, en particulier en ce qui concerne le rôle joué par l'idéologie et la pratique de la planification et de l'interventionnisme étatique dans la sphère économique. Dans le cas de l'État de Minas Gerais, ceci a permis à la classe professionnelle des ingénieurs de parvenir aux hauts sommets de l'État et d'accéder à des postes de prises de décision, avec des répercussions qui se firent sentir autant dans l'élaboration que dans la mise en œuvre des projets de développement économique régional, notamment dans les domaines de l'agriculture et de l'acier. C'est pour cette raison que l'analyse donnera la priorité à deux groupes spécifiques au sein de cette élite professionnelle: les anciens élèves de l'École des Mines de la ville d'Ouro Preto (EMOP) et les étudiants et professeurs de l'École Supérieure d'Agronomie et Vétérinaire de la ville de Viçosa (ESAV).

Mots-CLÉs: Élites techniques, développement, agriculture, sidérurgie, ESAV, EMOP.

Daniel Henrique Diniz Barbosa - Historiador pela Universidade Federal de Ouro Preto - Minas Gerais. Mestre em História pela Universidade Federal de Minas Gerais. Doutorando do Programa de Pós-Graduação em História Econômica da Universidade de São Paulo. Professor do Instituto Federal de Minas Gerais e pesquisador associado ao Núcleo de Pesquisa em História Econômica e Demográfica do Cedeplar - Face/ UFMG. Atua principalmente em História do Brasil República, particularmente nos seguintes campos relacionados à História de Minas Gerais: elites técnicas, siderurgia, energia elétrica, planejamento econômico e desenvolvimento regional.

Lidiany Silva Barbosa - Historiadora formada na Universidade Federal de Ouro Preto - Minas Gerais, com mestrado em Extensão Rural, pelo Departamento de Economia Rural da Universidade Federal de Viçosa. Doutoranda do Programa de Pós-Graduação em História Social da Universidade Federal do Rio de Janeiro, bolsista do CNPq e pesquisadora associada ao Núcleo de Pesquisa em História Econômica e Demográfica do Cedeplar - Face/UFMG. Atua especialmente em História do Brasil Império e História do Brasil República, notadamente nos seguintes campos relacionados ao processo de modernização de Minas Gerais: elites técnicas, elites econômicas, transportes, agricultura e desenvolvimento regional. 